\title{
The Implementation of biofloc systems in the catfish breeding cooperated with Lele Tamora SME
}

\author{
Cut Fatimah Zuhra $^{1 *}$, Sovia Lenny ${ }^{1}$, Nunuk Priyani ${ }^{2}$ \\ ${ }^{1}$ Department of Chemistry, Faculty of Mathematics and Natural Sciences, Universitas Sumatera \\ Utara \\ ${ }^{2}$ Department of Biology, Faculty of Mathematics and Natural Sciences, Universitas Sumatera \\ Utara \\ *Email: cutfatimah@usu.ac.id
}

\begin{abstract}
This community service aims to provide solutions for fisheries that experience water change problems caused by the lower availability of ground water. The small-medium enterprise (SME) Lele Tamora which is engaged in catfish breeding experiences this problem, such as turbid and bubbly water, which causes mass death of fish seedlings. Therefore, pond fish farming with a modern system integrated by a biofloc system that is supported by the use of microbubbles is introduced to the owner. The basic principle of this system is to utilize bacteria that can release substances that function as adhesives to form biofloc, such as microalgae aggregates, residual pellets, exoskeletons of dead organisms, bacteria, protists, protozoa and others substance with 0.1-2 mm diameter. All of these aggregates can be a source of poison in the pond system or as a competitor for fish to get oxygen. The biofloc system is projected to be able in reducing the toxic content in pond water which automatically reduces fish mortality, and this system can also convert organic waste in ponds into natural food as well as reducing commercial feed. For this purpose, a 1000 liter volume of bioreactor has been constructed to grow biofloc bacterial seeds, 20-liter-capacity of autoclaves to sterilize dissolved oxygen while helping to breed floc-forming aerobic bacteria. This system has been implemented at Lele Tamora SME, and the results showed the changing of water-pond colour from green to brown. Meanwhile, the netting ratio (selection of catfish based on the size of ready-to-sell) increased from 4000 to 8000 individuals.
\end{abstract}

Keyword: Microbubbles, bioflok, fish ponds, natural feeding

\begin{abstract}
Abstrak
Kegiatan pengabdian pada masyarakat ini dimaksudkan untuk memberikan solusi pada perikanaan yang mengalami masalah pada pergantian air disebabkan oleh ketersediaan air tanah semakin berkurang. UMKM Lele Tamora yang bergerak di bidang pembibitan lele adalah salah satu umkm perikanan yang mengeluhkan masalah ini, mengeluhkan air kolam berbau dan berbuih yang menyebabkan kematian massal bibit ikan. Oleh karena itu diperkenalkan budidaya ikan kolam dengan sistem modern yaitu sistem bioflok yang didukung oleh penggunaan mikrobubble. Dasar kerja sistem ini adalah memanfaatkan bakteri yang dapat mengeluarkan zat seperti lendir yang berfungsi sebagai perekat untuk membentuk bioflok, yaitu agregat mikroalga, pelet sisa, eksoskeleton organisme mati, bakteri, protista, protozoa dan lain-lain yang berdiameter 0,1-2 mm. Agregatagregat tersebut bisa menjadi sumber racun di dalam system kolam atau sebagai pesaing bagi ikan untuk mendapatkan oksigen. Diharapkan system bioflok ini dapat mengurangi kandungan racun dalam air kolam, yang dengan sendirinya mengurangi angka kematian ikan, juga dapat mengubah sampah organik dalam kolam menjadi pakan alami sehingga dapat mengurangi pemakaian pakan komersil. Untuk tujuan dimaksud telah dikonstruksi bioreaktor volume 1000 liter untuk menumbuh kembangkan bibit bakteri bioflok, autoklaf 20 liter untuk mensterilkan bahan dari mikroba lain dan mikrobubel generator untuk meningkatkan kualitas air kolam dengan meningkatkan kandungan oksigen terlarut sekaligus membantu pembiakan bakteri aerob pembentuk flok. Sistem ini telah diimplementasikan pada UMKM Lele Tamora. Hasil implementasi menujukkan bahwa warna air kolam berubah dari hijau menjadi warna kecoklatan dan rasio penjaringan (pemilihan lele berdasarkan ukuran siap jual) meningkat dari 4000 ekor perkolam menjadi 8000 ekor.
\end{abstract}

Kata Kunci : Mikrobubble, bioflok, perikanan kolam, pakan alami 


\section{PENDAhuluan}

Dewasa ini ketersediaan air tanah semakin berkurang. Hal ini berpengaruh hingga sektor perikanan dimana pergantian air sulit dilakukan sehingga kualitas air menjadi buruk, berbau dan berbuih. Kotoran ikan dan sisa pakan yang tidak habis adalah salah satu sumber racun dalam system kolam. Pakan ikan mengandung protein tinggi sekitar 30\%, akan terurai menjadi ammonia yang berbau busuk. Selanjutnya ammonia ini pada saat terjadi kenaikan suhu dan keadaan basa akan terurai menjadi nitrit yang bersifat racun, menjadi salah satu penyebab kematian ikan. Pada perikanan konvensional juga patut diduga bahwa kelarutan oksigen kedalam air kolam adalah rendah tidak memenuhi biologycal oxygen demand. Oksigen diperlukan oleh ikan untuk bernafas. Kekurangan oksigen menyebabkan ikan menjadi lemas, tidak bernafsu makan yang pada akhirnya dapat menyebabkan kematian.

UMKM Lele Tamora adalah mitra pada kegiatan pengabdian ini, bergerak dibidang perikanan dan mengalami masalah tersebut. Mitra menjelaskan bahwa kadang-kadang air kolam berbuih dan bersamaan dengan itu terjadi kematian massal, bangkai ikan melayang dan mengapung dipermukaan air. Mitra melakukan usaha budidaya bibit ikan lele secara konvensional menggunakan kolam tanah sebanyak 38 kolam ukuran rata-rata $3 \times 7 \mathrm{~m} 2$. Mitra memiliki induk hingga 200 ekor, menghasilkan sekitar 500.000 ekor anak perbulan. Anak-anak ikan lele ini dibesarkan hingga berukuran 2-3 cm (20-26 hari), 3-5 cm (26-30 hari) dan 5-8 cm (30-35 hari). Jumlah selamat hingga masa perjualan sekitar 300.000 ekor. Mitra biasanya didatangi oleh para pembeli tanpa harus menjual keluar area budidaya karena sudah memiliki langganan tetap. Menurut mitra, permintaan bibit lele biasanya hingga 400.000-500.000 ekor perbulan. Sampai sekarang permintaan ini belum dapat dipenuhi.

Untuk menyelesaikan masalah yang dihadapi mitra, maka kami memperkenalkan sistem bioflok yang dimodifikasi dengan penggunaan mikrobubble. Bioflok merupakan agregat mikroalga, pelet sisa, eksoskeleton organisme mati, bakteri, protista, protozoa dan lain-lain yang berdiameter 0,1-2 $\mathrm{mm}$. Agregat tersebut terbentuk oleh bakteri pembentuk flok seperti bacillus subtilis atau bacillus cereus, yang dapat mengeluarkan zat seperti lendir yang berfungsi sebagai perekat. Bahan-bahan organik itu mengandung nutrisi baik dan dapat menjadi pakan alami ikan, sehingga jumlah pakan pelet yang diberikan bisa dikurangi. Pengurangan jumlah pakan ini akan mengurangi biaya budidaya dan pada akhirnya akan meningkatkan pendapatan masyarakat. Sistem bioflok mensyaratkan adanya bakteri probiotik pembentuk flok. Kotoran ikan dan sisa pakan yang dapat menjadi sumber ammonia akan dimanfaatkan oleh bakteri untuk memperbanyak dirinya sehingga kadar ammonia di dalam air akan berkurang sehingga air kolam tidak mengeluarkan bau busuk dan kandungan racun dapat dihilangkan. Banyaknya jumlah bakteri probiotik ini juga akan menekan pertumbuhan bakteri dan jamur patogen lain di dalam kolam yang menyebabkan penyakit pada ikan sehingga dengan sistem ini ikan budidaya akan menjadi lebih sehat dan jumlah ikan yang mati dapat dikurangi. Bakteri pembentuk flok ini membutuhkan sumber energi untuk melakukan aktivitasnya, karena itulah dalam sistem bioflok ini diperlukan sumber karbon tambahan seperti molases, tepung tapioka, tepung terigu, bekatul atau gula.

Untuk memenuhi kebutuhan akan jumlah oksigen terlarut yang banyak dan proses pengadukan air kolam, maka digunakanlah teknologi mikrobubble generator (MBG). MBG adalah alat yang dapat menghasilkan gelembung udara sangat kecil berdiameter kurang dari $200 \mu \mathrm{m}$ sehingga lebih mudah larut di dalam air.

Peran MBG pada sistem bioflok ini sangat vital. Fungsi utamanya adalah untuk menyediakan jumlah oksigen yang banyak yang dipergunakan oleh ikan budidaya itu sendiri dan oleh bakteri pembentuk flok. Bakteri pembentuk flok adalah jenis bakteri aerob. Artinya jenis bakteri yang membutuhkan banyak oksigen untuk proses metabolismenya karena itu proses ini memerlukan oksigen yang cukup tinggi yaitu $4 \mathrm{ppm}$ pada siang hari dan $6 \mathrm{ppm}$ pada malam hari. Oksigen ini juga akan bereaksi dengan ammonia membentuk nitrit dengan bantuan bakteri nitrosomonas, kemudian nitrit ini yang bersifat racun akan diubah menjadi nitrat yang tidak bersifat racun, menjadi pupuk bagi fito plankton dan mikro alga yang merupakan bagian dari 
pakan alami atau flok yang terbentuk. Gelembung-gelembung mikro dari MBG juga akan mengangkat gas-gas beracun yang terdapat di dalam kolam seperti ammonia dan H2S ke udara. Disamping itu, aliran air dan mikrobubble yang keluar dari outlet pompa memiliki kecepatan tinggi sehigga berfungsi sebagai pengaduk yang akan memicu terjadinya flok lebih banyak. Flokflok ini akan melayang ke atas permukaan air kolam sehingga merangsang ikan untuk memakannya.

\section{METODE PELAKSANAAN}

Pelaksanaan kegiatan pengabdian masyarakat diawali dari diskusi dengan mitra tentang permasalahan yang dihadapi. Selanjutnya tim pelaksana kegiatan pengabdian pada masyarakat dari perguruan tinggi pembina menjelaskan sistem bioflok yang dapat menjadi solusi masalah yang dihadapi mitra, menjelaskan peralatan-peralatan peralatan yang diperlukan dalam system bioflok dan memberikan pelatihan cara pembuatan dan implementasi bioflok.

a. Pembuatan Auktoklaf

Autoklaf dibuat dari tabung aluminium berukuran 20 liter. Autoklaf dilengkapi dengan pengukur suhu dan tekanan, keran manual pelepasan udara dan safety valve. Gasket kedap udara terbuat dari bahan yang kuat terhadap suhu, asam, basa dan tekanan. Bahan-bahan pembuatan auktoklaf didapatkan dari pasar lokal, dan autoklaf dibuat pleh pengrajin lokal.

b. Pembuatan Generator Mikrobuble

MBG dibuat dari pompa air seperti terlihat pada gambar. Bahan-bahan yang diperlukan seperti pipa paralon dengan ukuran $3 / 4$ inci, socket, elbow, tabung venturi, lem, drat, barometer, dan vacuum meter dibeli di pasar lokal, yang selanjutnya dibawa ke pengrajin untuk dapat dikonstruksikan sesuai dengan rancangan yang dibuat.

c. Pembuatan Bioreaktor

Bioreaktor dibuat dari tandon air 1000 Liter, dilengkapi dengan dinamo pemutar, pengatur RPM (gearbox), kompresor oilless, blade pengaduk dari stainless steel, aerator berbentuk spiral yang diletakkan didasar reactor, pembuangan gas alir dilengkapi dengan katup satu arah dan dipasangi rangka.

d. Pembiakan Bakteri Probiotik Pembentuk Flok.

Starter bakteri bioflok yaitu bacillus subtilis atau bacillus cereus didapatkan dari pasar lokal dan dibiakkan menggunakan bioreaktor. Sebelum dibiakkan, dilakukan sterilisasi bahan dan alat agar mikroorganisme lainnya tidak terikut di dalam pembiakan menggunakan autoklaf.

e. Penyuluhan Implementasi Bioflok

1. Secara rinci, langkah-langkah yang dilakukan oleh perguruan tinggi pembina bersama mitra sebagai berikut:

2. Menjelaskan keunggulan dan keuntungan budidaya perikanan dengan sistem bioflok yang menggunakan teknologi MBG

3. Memberi penjelasan fungsi dari setiap bagian MBG dan peragaan cara mengoperasikannya.

4. Memberi penjelasan manfaat probiotik pembentuk flok, cara mengembangbiakkkan dan memperagakan pemakaian bioreactor.

5. Memperagakan cara mengimplemetasikan system bioflok pada kolam bibit ikan.

\section{HASIL DAN PEMBAHASAN}

Pengamatan dibantu oleh mitra. Pengamatan meliputi perhatian pada warna air, apakah masih munculnya buih di kolam, tingkat kematian ikan dan perubahan jumlah pakan ikan. Pengamatan dilakukan pada satu kolam yaitu kolam panen terakhir.

Setelah implementasi bioflok, didapatkan bahwa warna hijau pada air menjadi berkurang dan warna air menjadi agak coklat. Diperkirakan perubahan warna air ini disebabkan oleh tertangkapnya fito planton yang melayang di kolam dan membentuk flok. 
Buih yang kadang-kadang muncul, biasanya pada pagi hari, diamati tidak muncul lagi setidaknya selama rentang masa pengamatan. Pengamatan jumlah kematian tidak dapat dihitung, jumlah ikan mati hanya bias dihitung bias sedang terjadi buih dikolam dimana ikan mati melayang keatas permukaan air.

Tidak didapati pengurangan pada jumlah pakan yang dipakai, jumlah pakan sama antara dengan sistem bioflok atau tanpa sistem bioflok

Yang teramati sebagi hasil adalah, jumlah bibit terjaring meningkat dua kali lipat, yang biasanya sekali penjaringan. Penjaringan adalah proses pemisahan bibit ikan berdasarkan ukuran. Biasanya jumlah bibit panenan yang terjaring adalah rata-rata 4000 ekor, setelah implementasi bioflok menjadi rata-rata 8000 ekor. Penjaringan ini dilakukan setiap minggu.

\section{KESIMPULAN}

Implementasikan budidaya modern ikan kolam dengan sistem bioflok telah implementasikan pada UMKM Lele Tamora sebagai mitra pengabdian pada masyarakat. Peralatan telah di ujicoba dan berhasil dengan baik terutama dalam meningkatkan jumlah bibit terjaring siap panen

\section{UCAPAN TERIMAKASIH}

Pengabdian Kepada Masyarakat dibiayai oleh NON PNBP USU sesuai Kontrak Pelaksanaan Pengabdian Kepada Masyarakat, Program Multi Tahun, Tahun Anggaran 2019 Nomor: 327/UN5.2.3.2.1/PPM/2019 Tanggal 20 Mei 2019.

\section{DAFTAR PUSTAKA}

Ilham, Z., Muhammad, S \& Muliari. (2017). Pengaruh Penambahan Bioflok Dengan Dosis Berbeda Terhadap Pertumbuhan Benih Udang Windu, AL-KAUNIYAH; Journal of Biology, 11(1), 1-8

J. Ekasari. (2009). Teknologi Biotlok: Teori dan Aplikasi dalam Perikanan Budidaya Sistem Intensif, Jumal Akuakultur Indonesia, 8(2), 117-126.

Putri Endang Pebrihanifa. 2016. Pemanfaatan Bioflok Sebagai Sumber Pakan. Jurusan Budidaya Perairan Fakultas Pertanian Universitas Lampung 